\title{
Exploring the Unique Aspects of the Northern Social Economy of Food through a Complexity Lens
}

\author{
Connie Nelson \\ Lakehead University \\ Mirella Stroink \\ Lakehead University
}

\begin{abstract}
This article explores our observations on the ways that a social economy of food emerges out of context and place in Northwestern Ontario. We use a theoretical approach that draws on concepts from complexity science to better understand how the diversity inherent in context and place enables the unique social, ecological, and economic features of four case study initiatives. Our analysis of these social economy of food case studies reveals areas where the social economy appears to function differently in Northwestern Ontario, and this divergence from the literature is the focus of the article. We suggest three unique processes: first, a blending of social and capitalist economies; second, limitations of the capitalist economy in this northern setting; and third, the impact of connections with the unique landscape of Northwestern Ontario. We see people in pursuit of livelihood and well-being who are connecting and interacting as complex systems, thereby adapting dynamically through feedback loops to their total ecosystem (social/economic and biophysical), and producing diverse economic and social benefits. The resulting diversity and innovation build wellbeing, adaptation, and resilience in Northwestern Ontario communities as local food initiatives are strengthened.
\end{abstract}




\section{Introduction}

Economic practices that have a social focus collectively form what is called the social economy. Such practices and the thinking that underlies them are evident around the world and throughout history (Amin, 2009). Western scholars typically trace the roots of social economy to the associative and co-operative movements of the eighteenth and nineteenth centuries (Ott, 1851; Walras, 1896; Jennings, 2012). From there, in distinct anglophone and francophone traditions, the term has been used to describe a range of initiatives, from small enterprises generating social benefits, to transformative activities supporting wider movements for social justice (Moulaert \& Ailenei, 2005). The common thread across this diversity is the explicit aim of pursuing both social and economic goals while prioritizing the social (Sonnino \& Trevarthen-Griggs, 2013). In more recent efforts to describe the diversity of initiatives that form the social economy, the focus has shifted to describing their common characteristics, principles, objectives, and organization methods. The following principles, the origins of which are credited to Chantier de l'économie sociale, are now widely accepted as central principles of a social economy, which work well for both market and social-oriented activities (Defourny \& Develterre, 1999; Canadian Community Economic Development Network, 2005): 1.Placing service to its members or the community ahead of profit; 2 . Autonomous management; and 3. A democratic decision-making process.

There has been little research to date on the social economy in northern communities, yet arguably the joint pursuit of livelihood and social outcomes is deeply embedded in the practices of northern communities, both historically and presently (Southcott, 2009; Southcott \& Walker, 2009). Indeed, the social economy, which scholars describe as either a transformative action against the capitalist neo-liberal economy, or as an attempt to fill the gaps left by that economy, may be uniquely adapted to the social and ecological environment of the North. Our analysis shows that the emergence of the social economy in Northwestern Ontario predates "social economy" as historically described in the context of a European innovation.

The insights presented in this article came out of a larger project on the social economy of food, in which we examined four case studies of local 
food initiatives in Northwestern Ontario, representing municipalities, nonprofits, small business entrepreneurs, and First Nations (Nelson et al.,2019). Through that work and our ongoing exploration of complexity theory, we discovered that northern livelihoods, expressed as complex systems, reveal the social economy in ways unique to the North. In this article we draw on our case studies to demonstrate ways in which these Northwestern Ontario social economies are different from those described in the broader literature, and to discuss, using a complexity science approach, some of the place-based reasons for why these variations occur. Therefore, food and the place-based acquisition of food is a feature in this work, but our current focus is on the unique aspects of northern social economy initiatives, with food as a context. In identifying the unique place-based elements of this northern social economy of food and exploring why they occur, we will discuss how the social economy in Northwestern Ontario may predate social economies of associations and co-operatives as discussed in the European-based scholarly work of the eighteenth and nineteenth centuries.

\section{Social Economy as Place-Based}

Context and place shape the social economy (Tremblay, 2012; Jan, 2009). Dynamics that create conditions favourable to a successful social economy within a particular place seem to be context specific (Amin, Cameron, \& Hudson, 2002). Indeed, the specific culture of the group or community is an influential local characteristic that shapes social economy initiatives. (Defourny \& Develterre, 1999). Tremblay (2012) suggests that the reason there are such varied definitions of social economy is because social economies arise organically from local conditions. As communities of people interact with each other and with their unique contexts in pursuit of life and livelihood, they produce social economies that are emergent from and adapted to those unique contexts. Thus, as Jan (2009) advocates, it may be best to leave social economy as a fluid concept, rather than attempting to take the characteristics of one place to apply them in another location. The risk of transfer is to remove the specificity of both project and place and thus decontextualize local social economy initiatives (Amin, Cameron, \& Hudson, 2002).

Canada is recognized as a leader in encouraging communities to launch their own approaches to economic challenges, which will build 
community capability and also encourage an integrated approach to economic, environmental, and social initiatives (Chantier de l'économie Sociale, 2005). Defourney \& Develterre (2012) propose that this focus on context and place has created, in the last several decades, a different type of social economy that is community-based, has decentralized operations, and is independent of government intervention. Downing et al. (2012) similarly suggest that the social economy movement endorses a more people-centred approach to economic activities, which creates a distinct framework for socio-economic development.

Food is an essential organizing principle for communities of people, and food systems emerge as people interact with their ecological, economic, and social environments in search of sustenance. While food systems have a global reach in the capitalist economy, there is also an inherently local quality to food, making it an excellent context in which to explore the role of place in the social economy.

Given the interdependencies through which social economy emerges, we find the theory and concepts of complexity science to be a useful theoretical approach to the topic, and we draw these synergies throughout the discussion. We now provide a brief overview of this theoretical perspective and then introduce the setting of Northwestern Ontario and the methodology used in obtaining the case study data. We then present our analysis and selected observations from our case studies demonstrating the creative blend of resources, unique to Northwestern Ontario, that accomplish social benefits. We conclude with a discussion of why these unique elements have emerged in the region in light of the role of place in social economy and complexity science.

\section{Theoretical Approach}

Complexity science describes an approach and set of related theories and concepts from across several disciplines, including complex systems theory and complex adaptive systems theory, among others (Mitchell, 2009). Complexity science can contribute to understanding social economy features in local food initiatives (Nelson et al., in press), the dynamics of local food systems (Stroink \& Nelson, 2013), community engaged scholarship (Berinyuy et al., 2014), and more. There are many interrelated concepts in complexity science that collectively enhance understanding of human systems in their social-ecological context (Holling, 1973, 2001; Liu 
et al., 2007; Ostrom, 2009; Wiese, Vallacher, \& Strawinska, 2010). For example, complexity science concepts and research methods can explain how organized system-level properties that cannot be identified within or reduced to the behaviour of the individuals in the system can nevertheless emerge from the dynamic interactions of those individuals. Complexity science concepts can also explain how the continual dynamic adaptation of a system within the environment in which it is embedded can result in the appearance of both stability and transformation in the system. In these ways, complexity science offers a compelling lens through which to examine our case studies as examples of community food initiatives that have emerged as products of, and in continual adaptation with, their uniquely northern, but also diverse and dynamic, geographic, social, and cultural environments. Thus, in the current article, complexity science serves as a lens to assist in exploring how the total environment, or place, has impacted the unique emergence of the social economy in Northwestern Ontario. Here we briefly introduce some key concepts from complexity science that will assist in conceptualizing the unique aspects of social economy observed in our northern case studies.

A complex system occurs where a set of independent, yet interdependent, agents interact with each other and their context, producing, through these interactions, emergent system-wide patterns that are not predictable from the actions of the individual agents (Mitchell, 2009; Gunderson \& Holling, 2002; Weaver, 1948). Our social economy of food case studies are each comprised of many agents such as producers, processors, foragers, trainees, and consumers all of whom are independent in being able to make their own choices, but also interdependent in a network. Thus, the actions of one agent (e.g., foragers) affects the context for the others (e.g., consumers) who respond to this changed context thus changing the context again for the first group (e.g., foragers; see Figure 1). Through these interdependencies, the network of agents in each case study produces organized patterns of system-wide behaviour that would not be predictable from the actions of the individual agents. Complex systems adapt dynamically to their context through positive and negative feedback loops such that the actions of the system produce changes in the context that in turn either enhance or suppress these actions (Holland, 2006; Ostrom, 2010; Stacy, 1996; Ostrom, 1990). For example, immediate evidence of a social benefit impact of a local food initiative would be a tight 
positive feedback loop, serving to reinforce the system behaviours that produced that impact (see Figure 1). Organized system behaviour thus forms and stabilizes as a result of these feedback-driven dynamics without the need for external influence, prior design, or direction, a process termed self-organization (Ashby, 1962; Kauffman, 1993). When systems selforganize through tight feedback loops, they are able to respond quickly and adapt to changes in their environments.

Through the operation of multiple feedback loops, both within a given system and between that system and the full environment of other dynamic systems within which it adapts, complex and co-evolving system behaviour emerges. This dynamic and continual process of adaptation in a total environment that is itself dynamic produces periods of both stability and transformation in the system (Holling, 1973). Gunderson and Holling (2002) describe these dynamics of stability and change as a four-phase adaptive cycle of growth, conservation (stability), release (collapse), and reorganization. Resilience is an important concept in complexity science, particularly in the study of social-ecological systems and complex adaptive systems theory (Gunderson \& Holling, 2002; Holland, 2006). Resilience is defined as the capacity of a system to absorb disturbance and reorganize while undergoing change so as to still retain essentially the same function, structure, identity, and feedback (Walker \& Salt, 2006). In studying social economies, Batty \& Cole (2013) observe that resilience is more than just an economic attribute and is shaped by local interconnections and tight feedback loops that are a context-dependent process. Similarly, in studies of the community food sector, resilience appears stronger where social economies have localized meanings and goals (Sonnino \& TrevarthenGriggs, 2013; Bristow, 2010).

In our social economy case studies, we note the interdependencies of people pursuing life and livelihood in a full and dynamic environment of social (community), economic, and biophysical systems. We argue that these processes in our specific northern context, revealed through the lens of complexity science, demonstrate unique characteristics, consistent with social economy, but also different and rooted in adaptation to place. We now briefly explain the setting of our research and the methodology before turning to examples of how our case studies appear to operate differently as social economy initiatives. 


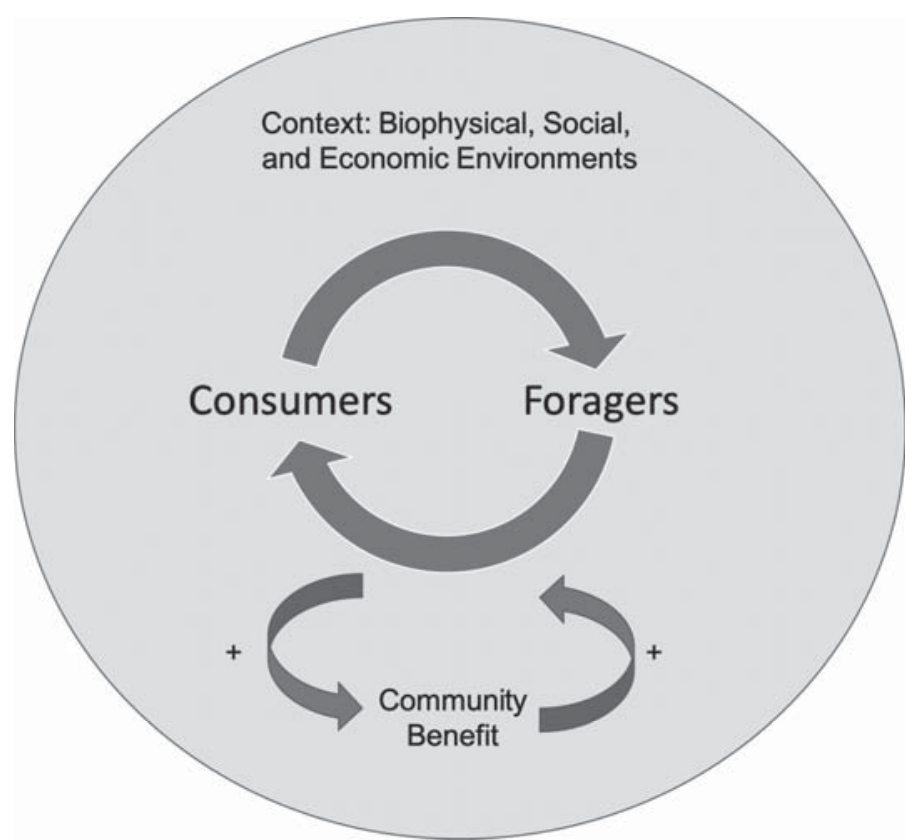

Figure I. Complex System Feedback Loop: Interdependencies among consumers and foragers with a feedback loop to community benefit

\section{Overview of the Study Region and Methodology}

\section{Northwestern Ontario}

Located in the geographic centre of Canada, Northwestern Ontario covers about $526,400 \mathrm{~km}^{2}$ and is home to a population of slightly less than 250,000. There are twenty-three municipalities with Thunder Bay and surrounding satellite communities comprising the only area with a population over 100,000 . In this region there are four treaties with jurisdiction over the Indigenous population of Ojibway, Cree, and OjiCree peoples living in eighty-eight First Nations. These treaties maintain the right of Indigenous peoples to hunt, fish, and gather as they have done for centuries and which are permitted for the sharing of land and resources (Indigenous and Northern Affairs Canada, Treaty 3, 5, 9 and Robinson Superior; Northwestern Ontario.ca) 
Methodology

This article emerged unexpectedly from a larger project funded by the Social Science and Humanities Research Council of Canada (SSHRC) to study the informal social economy of food and how it contributes to community prosperity. Specific foci of this research included low-income groups, Indigenous peoples, youth, and women. As the data was analyzed from our northern Ontario node, we were intrigued by results that showed unique responses to operationalizing the social economy in Northwestern Ontario. This article is the outcome from these unexpected findings.

The researchers have over a decade of community-based research experience working with local food systems in this region of Northern Ontario. During this time, we developed trusting relationships and an intimate knowledge of the regional local food system contexts (Stroink \& Nelson, 2009; Stroink \& Nelson, 2012; Stroink \& Nelson, 2013; Nelson \& Stroink, 2014). The nature of these relationships is consistent with Golden-Biddle \& Locke (1993). We demonstrate authenticity as our insights add to how northerners understand their world as it relates to food acquisition. We add plausibility to the interest in social economy as an alternative approach to a capitalist economy, and encourage criticality in broadening the understanding of social economy. We selected these four cases as diverse examples of local food initiatives that contribute to a social economy. This sample includes one food co-op, one non-profit, one First Nation, and a collective of four cases for the blueberry foraging social economy - two private initiatives, one municipal community, and one First Nation. In all four cases, participant observation data was used, with custom-made surveys with consumers and vendors in one case study and semi-structured interview guides in the other three. The time frame was September 2017 to April 2018. There was one research assistant per case study — three graduate students and one Honours Undergraduate. The methodology is more fully described in Nelson et al., 2019. Key features of the case studies are highlighted in Table 1. 


\section{Analysis}

These four case studies do indeed demonstrate key features of social economy initiatives as identified in the literature (Restakis, 2006; Amin, Cameron, \& Hudson, 2002; Ninacs, 2002; Mallory, McFeely, \& Connelly, 1999). For example, the goals, activities, and indicators of success for each initiative are focused on social and psychological benefits for individuals and communities, such as sense of purpose and connection; revenue is considered secondary, and as a means of sustaining the activities of the organization (see Nelson et al., forthcoming). As previously stated, the purpose of this study is to draw upon the four case studies to demonstrate ways in which these Northwestern Ontario social economy of food initiatives are different from the social economy literature and to discuss, using a complexity science approach, some of the place-based reasons for why these variations occur. We have identified three processes in which our case studies demonstrate unique social economy characteristics: (1) blended economies, (2) unique gaps, and (3) relationships with the land. We have selected examples from each case study to illustrate these three unique processes. These examples demonstrate that the central principles of a social economy, as outlined in the introduction, that work well for both market and social-oriented activities, appear to be distinctly different in Northwestern Ontario. For example, we find evidence of blended economies in this context, which may have historically relevant roots, compared to social economies elsewhere that consistently place community ahead of profits.

\section{Blended economies in the historical context of place in Northwestern Ontario}

The social economy has been described as driven either by an effort to fill the gaps left by an inadequate social welfare system in a capitalist economy or as a transformative effort to build social justice and disrupt the capitalist economy (Charron, 2012; Levesque \& Mendell, 2005; Moulaert \& Ailenei, 2005). The social economy initiatives in our case studies do not appear to be driven by either of these aims. Instead, we see people in pursuit of livelihood and well-being connecting and interacting as complex systems, thereby adapting to their total ecosystem (social/economic and biophysical) and producing diverse economic and social benefits. 
Table I. Social economy of food initiatives in Northwestern Ontario-Four case studies (adapted from Nelson et al., 2019)

\begin{tabular}{|c|c|c|}
\hline Name & Location & Key Features \\
\hline \multirow{3}{*}{$\begin{array}{l}\text { Bearskin Lake First } \\
\text { Nation } \\
\text { http://nourishingontario. } \\
\text { ca/the-social- } \\
\text { economy-of-food/ } \\
\frac{\text { case-studies-subversions- }}{\text { from-the-informal- }} \\
\underline{\text { and-social-economy/ }} \\
\underline{\text { the-social-economy-in- }} \\
\underline{\text { northwestern-ontario/ }}\end{array}$} & $\begin{array}{l}\text { In the Hudson Bay watershed, } \\
623 \mathrm{~km} \text { north of Thunder Bay; } \\
\text { accessible by air and winter ice } \\
\text { roads }\end{array}$ & $\begin{array}{l}\text { Participant observation by } \\
\text { graduate student research } \\
\text { assistant who is a member of } \\
\text { Bearskin FN }\end{array}$ \\
\hline & \multirow{2}{*}{$\begin{array}{l}\text { About } 50 \% \text { of the } 900 \text { population } \\
\text { is located at Michikin Lake, with } \\
\text { a significant percentage calling } \\
\text { Thunder Bay their place of } \\
\text { residence }\end{array}$} & $\begin{array}{l}\text { On-site informal interviews } \\
\text { with community members and } \\
\text { knowledge keepers of the land }\end{array}$ \\
\hline & & $\begin{array}{l}\text { Observed blending of traditional } \\
\text { means of living off the land with } \\
\text { outside food acquisition }\end{array}$ \\
\hline \multirow[t]{2}{*}{$\begin{array}{l}\text { Willow Springs } \\
\text { Creative Centre } \\
\text { (WSCC) } \\
\text { http://nourishingontario. } \\
\underline{\text { ca/willow-springs- }} \\
\underline{\text { creative-centrel }}\end{array}$} & \multirow[t]{2}{*}{$\begin{array}{l}\text { 3I km northwest of Thunder Bay } \\
\text { at an historic midway point for } \\
\text { Finnish farmers who bring eggs } \\
\text { and produce; shop for essential } \\
\text { supplies such as sugar, salt, and } \\
\text { flour; and have their eggs and } \\
\text { produce collectively transported } \\
\text { to Thunder Bay }\end{array}$} & $\begin{array}{l}\text { Continues historic mission of } \\
\text { being a midway point to assist } \\
\text { local producers and processors } \\
\text { to gain experience, knowledge of } \\
\text { food-related marketing policies, } \\
\text { and confidence in selling at } \\
\text { WSCC before scaling up to } \\
\text { Thunder Bay and other northern } \\
\text { destinations }\end{array}$ \\
\hline & & $\begin{array}{l}\text { Engages with the unique boreal } \\
\text { forest resources for therapeutic } \\
\text { programming. }\end{array}$ \\
\hline \multirow{3}{*}{$\begin{array}{l}\text { Cloverbelt Local Food } \\
\text { Co-op } \\
\text { http://nourishingontario. } \\
\text { ca/the-cloverbelt-local- } \\
\text { food-co-op/ }\end{array}$} & $\begin{array}{l}\text { Geopolitical centre is Dryden } \\
\text { with hubs located in Emo, Fort } \\
\text { Frances, Kenora, Red Lake, Sioux } \\
\text { Lookout, Ignace, and Upsala }\end{array}$ & \multirow{3}{*}{$\begin{array}{l}\text { Online Food Co-op with I,749 } \\
\text { consumer members, I } 20 \\
\text { producer members, } 3 \text { restaurants } \\
\text { featuring local food, and I } 3 \\
\text { organizational members. } \\
\text { Developing a Regional Food } \\
\text { Charter to support connectivity } \\
\text { in building the local food system. }\end{array}$} \\
\hline & $\begin{array}{l}\text { Central hub for produce and } \\
\text { processed local foods is in } \\
\text { Dryden, but local food from any } \\
\text { hub can be delivered to other } \\
\text { hubs }\end{array}$ & \\
\hline & $\begin{array}{l}\text { GIS mapping of all producers, } \\
\text { processors \& restaurants } \\
\text { specializing in local foods across } \\
\text { Northwestern Ontario }\end{array}$ & \\
\hline
\end{tabular}


Table I continued

\begin{tabular}{|c|c|c|}
\hline Name & Location & Key Features \\
\hline \multicolumn{3}{|l|}{$\begin{array}{l}\text { Blueberry foraging } \\
\text { initiatives }\end{array}$} \\
\hline \multicolumn{3}{|c|}{$\begin{array}{l}\text { http://nourishingontario.ca/blueberry-foraging-as-a-social- } \\
\text { economy-in-northern-ontario/ }\end{array}$} \\
\hline \multirow[t]{4}{*}{$\begin{array}{r}\text { Arloland } \\
\text { First Nation }\end{array}$} & $\begin{array}{l}370 \mathrm{~km} \text { northeast of Thunder } \\
\text { Bay. Acquired reserve status in }\end{array}$ & $\begin{array}{l}\text { Located on land that yields } \\
\text { abundant native wild blueberries }\end{array}$ \\
\hline & $\begin{array}{l}\text { 1985, with reserve lands totaling } \\
19,599 \text { ha. }\end{array}$ & \multirow{2}{*}{$\begin{array}{l}\text { Historically, blueberries were } \\
\text { transported along the } \mathrm{CN} \text { rail } \\
\text { line to other First Nations and } \\
\text { the Sioux Lookout area }\end{array}$} \\
\hline & $\begin{array}{l}\text { Off-reserve population } 400 \text { and } \\
\text { on-reserve population } 366\end{array}$ & \\
\hline & $\begin{array}{l}\text { Member of Nokiiwin Tribal } \\
\text { Council }\end{array}$ & $\begin{array}{l}\text { Blends traditional and market- } \\
\text { based food economy to provide } \\
\text { monetary income and nutritional } \\
\text { food }\end{array}$ \\
\hline \multirow[t]{4}{*}{ Blueberry Blast } & $\begin{array}{l}\text { II } 6 \mathrm{~km} \text { east of Thunder Bay } \\
\text { at the mouth of Nipigon River } \\
\text { where it enters Lake Superior }\end{array}$ & \multirow{4}{*}{$\begin{array}{l}\text { Blended economy begins with } \\
\text { Norma Fawcett's vision of } \\
\text { creating a festival honouring } \\
\text { the blueberry. Blended } \\
\text { successfully with Nipigon } \\
\text { Chamber of Commerce, which } \\
\text { supported tourism and local } \\
\text { business development, as } \\
\text { well as strengthened regional } \\
\text { community "fun and frolic" }\end{array}$} \\
\hline & Population I,630 & \\
\hline & $\begin{array}{l}\text { Next to Lake St. Helen Red } \\
\text { Rock Indian Band, independent } \\
\text { members of Union of Ontario } \\
\text { Indians. Population } 323\end{array}$ & \\
\hline & $\begin{array}{l}\text { Located on TransCanada Highway } \\
\text { at junction of Hwy } 17 \text { and II }\end{array}$ & \\
\hline \multirow[t]{4}{*}{$\begin{array}{l}\text { Arthur Shupe } \\
\text { Wild Foods }\end{array}$} & $\begin{array}{l}\text { Dryden, } 353 \mathrm{~km} \text { from Thunder } \\
\text { Bay }\end{array}$ & \multirow{2}{*}{$\begin{array}{l}\text { Early social economy that } \\
\text { provided alternative employment } \\
\text { from mining and forestry (for } \\
\text { over } 20 \text { years) }\end{array}$} \\
\hline & Population of Dryden 7,600 & \\
\hline & $\begin{array}{l}\text { Harvesting area may cover a } \\
\text { radius of } 300 \mathrm{~km} \text { from Dryden }\end{array}$ & $\begin{array}{l}\text { Finds social benefit in providing } \\
\text { berries, chantrelles, and morel } \\
\text { mushrooms at reasonable pricing } \\
\text { to those who are unable to pick }\end{array}$ \\
\hline & & $\begin{array}{l}\text { Picks seed cones for boreal } \\
\text { forest regeneration. }\end{array}$ \\
\hline \multirow[t]{2}{*}{ Algoma Highlands } & $\begin{array}{l}480 \mathrm{~km} \text { east of Thunder Bay } \\
\text { along Highway } 17 \text { on the shore } \\
\text { of Lake Superior }\end{array}$ & \multirow{2}{*}{$\begin{array}{l}\text { Blended economy of economic } \\
\text { diversification in area highly } \\
\text { impacted by mining and forestry } \\
\text { downsizing, with community } \\
\text { capacity building for alternative } \\
\text { employment in harvesting } \\
\text { and processing blueberries, } \\
\text { as well as for creating food, } \\
\text { drink, and artistic products } \\
\text { from blueberries; expansion to } \\
\text { rhubarb and raspberries. }\end{array}$} \\
\hline & $\begin{array}{l}\text { Planted native wild blueberries } \\
\text { on ancient beach }\end{array}$ & \\
\hline
\end{tabular}

Nelson \& Stroink | Northern Social Economy of Food 
The following examples demonstrate how people in our case studies engage toward adaptation simultaneously with their total environment, inclusive of biophysical and capitalist/economic ecosystems in pursuit of survival and well-being for themselves and their communities.

Bearskin Lake First Nation. Bearskin Lake is a remote Anishinaabe community in Northwestern Ontario. Food acquisition today is a blend of local food obtained through traditional practices of hunting, harvesting, and gathering from northern boreal forest resources, and outside food bought from the Northern Store or a local food co-op, where foods arrive by air or seasonal ice roads. Bearskin Lake's social economy food system has its roots in a history of food sourcing from the land blended with outside capitalist food that arrives by seasonal ice road or air freight. While conducting this research, we learned, through our Cloverbelt Local Food Coop (CLFC) case study, of a new initiative to bring CLFC food products to Bearskin Lake thus replacing some of the food sourced from outside Northwestern Ontario. This is an exciting and innovative initiative that can further blend the social economy of food system for Bearskin Lake First Nation. This initiative is viewed positively as an emphasis remains on traditional food sources augmented with a priority placed on regionally available local foods over capitalist food sources from elsewhere. Bearskin Lake members are emphatic about ensuring that they maintain a placebased food knowledge that will always ensure their survival if outside food sources are cut off.

Food is a connecting and relationship-building resource for key annual festivals such as the Hunters Festival and Jeremiah Days, and for most allcommunity events such as graduations, memorial celebrations, and church meetings. Social capital is enhanced by the community, which engages in local self-organized fundraisers, such as community bingos, penny sales, and flea markets, to ensure the viability of these community events. An adaptation to traditional sharing (that has always been an essential feature of local hunting, gathering, and harvesting from locally sourced foods) is innovatively augmented with sharing amongst the community and with nearby communities through the local "Michikan Auction Wars" Facebook page. Community members frequently cook "extra" and put these meals on Facebook to sell to others. Thus, the blended economy of Bearskin Lake uses innovative resources to enhance community survival and well-being. 
Blueberry Foraging: Aroland. By the last quarter of the eighteenth century, Ojibwa became a primary group in the forested part of Northwestern Ontario, and the region's residents assumed a culture based on patrilineal extended families managing specific tracts of land for hunting, trapping, fishing, and gathering (Dunning, 1959). At about the same time, summer settlement around Hudson's Bay Company (HBC) posts became a new trend as the fur trade became more established (Bishop, 1970). In such settlements, agricultural production became a way of commerce with fur traders and an additional means of subsistence, until Canada prohibited unregulated sale of produce in 1881 (Waisberg \& Holzkamm, 1993). Ojibwa peoples became more dependent once again on wild foods for subsistence. Aroland people settled in the vicinity of the $\mathrm{HBC}$ post established around 1900 on the northwest shore of Kawashkagama (Kowkash) Lake, near traditional hunting grounds at Esnagami Lake (Driben, 1986).Today, Aroland lays claim to the same tracts of family subsistence land that were established during the first settlements in the nineteenth century. In the last few decades, logging, adventure outfitting, and mining developments increasingly share these same areas.

Aroland First Nation is in a boreal forest area exceptionally abundant in native low bush blueberries (Vaccinium angustifolium, vaccinium myrtilloides, and vaccinium nigrum). Since 2009, the community has created a blended social economy where marketing some of the harvested blueberries sustains social benefits within the community. The initiative is called the Aroland Youth Benefit Initiative (AYBI), with a community advisory committee that carries out certain logistics like scouting for the best picking areas (which change from year to year depending on the abundance of rain in the Fall; amount of snow cover; early Spring frost exposure; and the government's glyphosate spray schedules for curtailing deciduous plant growth including blueberries); letting the community know when the berries are ready to be harvested; determining how much pickers will make per basket; and then arranging for the marketing of the blueberries.

AYBI has created a system where people can pick berries for themselves and for others who cannot pick, providing the the berries to AYBI for distribution. Thus, the whole community benefits. Aroland recognizes that they could grow into a large business but that is not the purpose or the desire of the community. Becoming a business is seen as unnecessary 
because they only want to provide support to the community. In other words, the current form of the initiative is inclusive with respect to the well-being of all community members and eliminates need for any type of employment sign-up form. Community members just show up at the blueberry sites. If they pick for others or the AYBI then they are paid by the Blueberry Community Committee. Pickers thus can support community well-being and provide community members with a way in which they can continue to practice traditional activities.

Blueberry Foraging: Nipigon Blueberry Blast. Wild blueberries are an important food source in rural communities of Northwestern Ontario. Food security and social enterprise development are increasingly recognized as essential factors in supporting community well-being (Food Secure Canada, 2017; Stroink and Nelson, 2013). This blended social economy began when Norma Fawcett, an Elder from the Lake Helen Reserve, had a vision of establishing a blueberry festival. Her purpose was to celebrate and honour the blueberry plant.

Over the years, the Blueberry Blast achieves such social benefits as boosting community spirit through encouraging participation and interaction of all age groups in picking berries, and in entertainment, food, and dance. Community members and visitors have an opportunity to have fun, get to know one another, and harvest nutritious berries. In parallel to these social benefits, the Blueberry Blast has contributed to making Nipigon a tourist destination that has positively impacted locally owned and operated businesses.

\section{Social economies address unique gaps left by the capitalist economy in Northwestern Ontario}

There are limitations to the reach of the neo-liberal economy as a survivalsustaining ecosystem, particularly noted in our more remote communities like Bearskin Lake First Nation, but also obvious in the widely separated but still road-accessible communities of our region. The capitalist economy does not have the same hegemonic reach in the North; it is more limited here by geography and the suitability of "one best way" food system policies applied homogeneously irrespective of unique and diverse environments. For example, the mechanisms of the capitalist economy do not in and of themselves enable the development of the transportation and distribution 
networks that are required for market access by small processors and producers in a large geographic area with sparse population. Instead, the volunteers behind Cloverbelt Local Food Co-op are using technology and other innovative approaches to generate these networks through a blended social economy. Following, we provide additional details, drawn from our case studies, of the limitations of the neo-liberal capitalist economy in Northwestern Ontario.

Cloverbelt Local Food Co-op (CLFC). CLFC emerged from a desire among farmers in the Dryden region to be better connected. Before CLFC was founded, there was a concern that the agricultural community was becoming smaller, disjointed, and not attracting new producers and processors. There were limited opportunities such as regional seasonal markets that required producers and processors to spend ten or more hours each week travelling to these widely-scattered markets rather than using this time for farm production and processing. Out of this desire to build capacity in regional food production, CLFC was founded as the first online co-op in Northwestern Ontario that could reach regional consumers while still being a practical option for both small local producers and processors to operate all year round.

Each week, producers and processors list their current products on the CLFC website before Thursday, and then consumers can log in and fill their orders with any products listed on the website, from Saturday to Monday morning. Once the ordering cycle closes, producers and processors work to fill orders by Tuesday when the regional distribution network begins transporting these orders to consumers in Dryden, Red Lake, Kenora, Emo, Fort Frances, Sioux Lookout, Upsala, and Ignace, who pick up Tuesday late afternoon. Consumers in other communities can go to one of these hubs to pick up their orders. This weekly cycle is beneficial for producers and processors to coordinate and ship their products together, reducing costs and the environmental impacts of transportation. In addition, because producers and processors decide each week how much of their product they want to make available, there is no pressure for them to meet specific quotas or quantities. This overcomes a huge obstacle for producing or processing in the neo-liberal economy where there is little opportunity for variation in products and/or in quantity of a product to be sold. Instead, through CLFC, producers and processors can adapt to 
changing seasons or test out new products. In addition, this innovative marketing system is appealing to many consumers because of the ease of ordering.

In order to support the collaboration of producers and processors across this vast region, $C L F C$ began a Food Mapping and Distribution Project that pinpoints the locations of local food contributors in Northwestern Ontario on an interactive online map (http://www.nwofoodmap.com), including producers, processors, distribution hub locations, processing facilities, and restaurants featuring local food. The map provides a description of local food contributors as well as their locations. Consumers know exactly where their food comes from and producers and processors can easily locate restaurants interested in serving local food. There is significant potential for the map to be used in the future for reciprocal trade in Northwestern Ontario fly-in communities, in order to sell northern fish or blueberries and to purchase from other Northwestern Ontario communities.

Willow Springs Creative Centre. WSCC is located in a rural area challenged by a short growing season and travel distance for local smallscale market gardeners to reach local food markets in the City of Thunder Bay. WSCC creatively recognized its location on a heavily travelled weekend and summer time road to several well-populated cottage areas (local expression is camps). The centre has used their local context to advantage and created a Friday afternoon market. Here, small-scale local producers and processors gain opportunities to learn how to prepare vegetables and locally raised meats for market. Through the opportunity to have a weekly market at WSCC (June-September), the vendors have learned how to package and meet provincial standards for home kitchen processing and labelling. There are over four hundred cottagers who travel past WSCC on Fridays to reach their camps. This market ensures cottagers and local residents ready access to locally raised and processed foods.

A small fee is charged by WSCC for vendor tables, which supports sustaining the open Friday market. WSCC has an artisan wood oven that is used for selling locally made pizzas through their training programme for adults with disability challenges. These trainees also learn skills in preparing for market foods such as cranberry wild rice bread, muffins, and cookies that are primarily made with local ingredients including locally grown and milled flour. Sales from the artisan pizza and other bakery 
items supports the Friday afternoon market. Profit is not the primary motivator for the establishment of the market, but rather providing local market gardeners with a small-scale market where they can practice selling skills and interactive skills with customers. The WSCC weekly market overcomes the limitation of the neo-liberal capitalist economy by enabling the development of the transportation and distribution networks that support market access by small processors and producers.

Blueberry Foraging: Algoma Highlands. In Northern Ontario 95\% of the land is considered Crown land. Growth and economic development on Crown land are limited to primary resource industries such as mining and forestry. Forest policies, land tenure, and forest management as a whole have all been designed to support the development of timberbased products through a small number of large multinational companies holding Sustainable Forest Licences (SFL) on most of this Crown land. Such a strong focus on mining and timber-based products has left little or no room for the emergence of alternative development opportunities in communities. There are no current policies that support licensing for commercial blueberry production on crown land or policies to support prescribed burns to periodically suppress competitive plant growth and soil regeneration so vital to thriving blueberry yields. So, in spite of the abundance of blueberries across the boreal forest of northern Ontario, policies have encouraged the neo-liberal capitalist economy for only timber and mining economic development. Downsizing in both forestry and mining in the Wawa area provided a unique opportunity for a social economy to emerge. Knowing that Crown land was still focused on policies for mining and forestry, Algoma Highland owners in 2006 purchased 640 acres on a unique geological site of $100 \%$ sand that thousands of years ago was an old Lake Superior beach. Under this perfect habitat condition for growing native blueberries, Algoma Highlands has successfully established a natural, sustainable, low-bush wild blueberry farm.

With their place-based knowledge of the area, Algoma Highland owners have innovatively created a blended social economy through economic diversification and community capacity building. Algoma offers local alternative employment opportunities for pickers and those who help process raw blueberries into jams, syrups, barbecue sauces, Wild Blueberry Mooseradish, and wine. Through their store, product expansion provides 
additional opportunities for marketing local raspberries and rhubarb. Local community arts and crafters are also encouraged to sell through the Algoma Highlands store that is situated on the TransCanada Highway, as well as market across Northwestern Ontario through the Cloverbelt Local Food Co-op online system.

Bearskin Lake First Nation. In Bearskin Lake we see how Indigenous peoples view the Western capitalist economy as time and space limited and as a temporary phase in the present world. Utchene (Oji-Cree) shapes a strong community spiritual balance where negative responses to outside impacts on the food system are never displayed. Exhibiting negativeness may create feedback that disturbs healthy positive well-being that can impact on the community as well as individuals and family members. Utchene encourages goodness, which creates a healthy environment for obtaining food security. Bearskin Lake First Nation practises a traditional culture that holds distinctive Indigenous ways of knowing, balance, and relationship with land and water. Sturgeon has been a part of food security for thousands of years. When the provincial ministry developed policy that identified sturgeon fish as a species at risk, there was resistance, but it will never be publicly spoken in fear of upsetting Utchene.

For Bearskin Lake the "law of the land" is practised whereby in-depth feedback is constantly active to assess what is happening within ecosystemhuman relations. "Law of the land" with in-depth feedback of the local ecological system, including humans, is a distinctly separate paradigm from government policy and regulations of mainstream economy. The community prefers intra-community trade with neighbouring communities in order to develop adaptive resiliency (neighbouring communities in this context means communities that are close enough to reach by all-terrain vehicles, boat, or snow machines). If trade is independent of the neoliberal economy and government money, the Bearskin Lake community believes that Utchene can be maintained. There are ongoing discussions with traditional knowledge keepers on the possibility of developing a commercial fishing licence as a source of income in order to provide more food security among Indigenous communities. 


\section{Strong Relationship with the Land in Northwestern Ontario}

All of our social economy case studies have roots in the boreal forest land, which is the predominant ecological feature in Northwestern Ontario. This land has shaped survival and livelihood as exemplified here.

Blueberry Foraging: Nipigon Blueberry Blast. To bring awareness of the traditional practice of berry picking to everyone, the Blueberry Blast formed in 2002. Providing access to blueberries continues as an important function of the Blueberry Blast. The festival forges a collective community identity around a natural local food resource. Blueberry picking is part of the identity of many people in the area as they connect with the land. Many have lifelong memories of picking berries as a child. Through blueberry picking, an increased social network of trust is built between oneself, nature, and other community members. The main objective of honouring the blueberry and encouraging awareness of a locally available food source, while respecting the environment, remains.

Blueberry Foraging: Arthur Schupe Wild Foods. For over two decades Arthur Schupe has accessed native wild blueberries, chanterelles, and morel mushrooms on Crown land. The abundance of Crown land open for the public to access natural resources has encouraged Schupe to develop a social enterprise in wild foods. Schupe has benefited from the regional outreach of CLFC to support both wild and cultivated foods. Previously, he had been driving his wild foods five hours to Thunder Bay.Jen Springett, president of CLFC, explains it this way:

Wild harvested foods are a critical element of local food security in our region .... Our Co-op is committed to supporting forest and freshwater food entrepreneurs .... Not to mention the added benefits of including wild foods in our diets. For instance, they are typically higher in nutrients than their commercial counterparts. They occur naturally, which means when harvested sustainably, they are an environmentally friendly option (fertilizers, water, and the burning of fuel to prepare soil were not necessary), and they were not sprayed with herbicides or pesticides. 
Bearskin Lake First Nation. Food resourcing has a strong impact on cultural identity. Hunting, harvesting, and gathering activities reinforce and regenerate skills and knowledge of the land as the source of food and survival. Place-based learning emphasizes the exchange of knowledge most relevant to building a resilient local food system through feedback intensely connected to the people and their setting. Bearskin Lake community members are grounded in the local bioregion, and traditional food acquisition practices reinforce the history and culture of the community. Maintaining and rekindling traditional ways of food sourcing is profoundly place-based, experiential, and holistic.

Ties to the land are thousands of years in the making and shape a member's identity and purpose. Identity is deeply embedded in the land, which is the traditional giver of food. Members of the Bearskin Lake First Nation show resilience in adapting their lifestyles to environmental changes that affect their sources of food. Traditional hunting camps are further north of the community. Currently, planes are chartered annually to reach these traditional food sources.

Cloverbelt Local Food Coop. The richness of the Cloverbelt land base around Dryden is a legacy from unique clay deposits left over from the ancient Lake Agassiz. According to the early pioneers, the knowledge of how to work with the land to produce food was experientially acquired and passed on to next generations. The food producers have learned from working with the land how to take advantage of its strengths of warm summers with extended hours of sunlight, and to develop innovative intensive food production skills for meat, vegetables, and grains in order to overcome the shortness of the growing season.

Willow Springs Creative Centre. WSCC has blended educational programming that provides a source of sustainable income through innovatively using the surrounding boreal forest resources for social benefit by offering horticultural therapy programming to people served by social service agencies in the Thunder Bay region. Horticulture therapy (HT) programming at WSCC has become an ideal location to facilitate the exchange and development of food knowledge that is grounded in place, in the reality of the land and the life it encompasses. All of these HT programming initiatives build on the concept of no artificial boundaries 
between the boreal forest as a natural garden and cultivated gardens. HT provides ideal opportunities for development of sustainable food systems knowledge and place-based learning that uses interaction with local plants to improve social, cognitive, physical, and general well-being. HT encourages an interconnectedness with the living external environment that uses available resources to enhance survival, purpose, and connection.

WSCC now provides therapeutic gardening programs in long-term care facilities, treatment centres, and schools, as well as with different community organizations such as Autism Ontario, and with the Food Security Research Network (FSRN) Campus Community Garden. WSCC is also currently working in partnership with FSRN at Lakehead University to develop a four-course certification program in horticultural therapy. This latter initiative intensifies opportunities for WSCC to create additional certified horticultural therapists with specialized training in the use of boreal-forest-cultivated and forest gardens as the focal point for additional therapeutic benefits.

\section{Discussion}

In summary, we presented four case studies that demonstrate ways in which the social economy of food operates uniquely in Northwestern Ontario. We identified three such unique processes. The first was that the case studies demonstrate a blending of social and capitalist economies. The second was that the capitalist economy has unique limitations in this northern setting around which the studied initiatives have formed and adapted. The third was that connection and identification with land and place has a particular impact on the social economy initiatives studied. Throughout our analysis of these case studies the critical role of place in shaping social economies was evident. In this section we will discuss these three unique processes, suggest some possible reasons for these variations with particular attention to research on place, and use complexity science as a lens for this work.

\section{Blending of economies}

Our first primary observation from these case studies is that they are driven by people building livelihood with personal and social benefits in place, leveraging the resources of the land and the social and capitalist economies to do so. In this way, these cases stand apart from the bulk of the social economy literature, which sees social economy initiatives as 
being driven by either an effort to address gaps left by the social welfare system in a capitalist economy or as a transformative effort to build social justice and disrupt the capitalist economy (Charron, 2012; Levesque \& Mendell, 2005; Moulaert \& Ailenei, 2005). Our four case studies reveal that the capitalist and social economies in Northwestern Ontario are entangled. People are working in pursuit of livelihood and well-being in adaptation with their total environment. This total environment includes the biophysical land, the capitalist economy, and the social community as interdependent ecosystems. Our observations are supported by Nyssens \& Petrella (2010) who bring together Ostrom's (1990) work on common pool resources and argue the need to move past a state-market dichotomy, recognizing the complexity and plurality of a social economy. They refer to the dynamics of a social economy as recognizing and understanding of an "eco-diversity" that blends the social, economic, and biophysical in an all-encompassing ecosystem.

This notion of an all-encompassing ecosystem is consistent with a complexity science lens. People are agents acting independently in pursuit of goals such as survival and well-being. In pursuing these goals, they interact with each other and thus become interdependent in a network. Through feedback loops, this human system adapts dynamically within its social, economic, and biophysical environments. An order or pattern self-organizes, which becomes structured and stabilizes the system for a time, until that structure is released and reorganized in adaptation with a changing context as in the adaptive cycle (Gunderson \& Holling, 2002). In our case studies, people exchange goods (food) and resources with each other and in interaction with the land in ways that blend or cross more freely among the biophysical environment, social or community environment, and economic environment to produce an overall human ecosystem. Further supporting our observational analysis are the early writings of Gide (1912) who recognized that social economies function as natural laws where relations between people and their environment function as natural systems (in Moulaert \& Ailenei, 2005).

\section{Limitations of capitalist economy}

Our second primary observation in these case studies was that the capitalist economy has additional unique limitations in Northwestern Ontario, beyond those relating to social welfare seen in the social economy 
literature (Moulaert \& Ailenei, 2005). The ability to sustain life by relying solely on the capitalist economy is more tenuous, particularly in the more isolated and Indigenous communities, but also those communities strung along isolated roadways that depend on truck transport for commercial food delivery from major centres thousands of kilometres away. As a result, the capitalist economy may not have the same hegemonic reach, the same dominance in the awareness of the public who must depend on each other and on the land more often to address survival needs, or for whom the possibility of having to do so is more salient. Thus, we saw the members of Cloverbelt Local Food Co-op working together to generate a transportation network, and both Cloverbelt and Bearskin Lake First Nation using technology to enhance regional communication and trade. These limitations of the capitalist economy give a unique and urgent flavour to the social economy of food in Northwestern Ontario reminiscent of the fundamentally place-based nature of social economy (Amin, Cameron, \& Hudson, 2002; Defourny \& Develterre, 1999).

The capitalist economy is further limited in Northwestern Ontario in that the policy and legislation that support it in more populated areas do not work as effectively in these communities. For example, in each of the blueberry foraging case studies, there was discussion of the challenges presented by legislation governing Crown land that is focused on the timber industry. This legislation favours resource extraction for the capitalist economy (which does provide some employment within the capitalist economy in the area), but undermines foraging activities that support the social economy. Such legislative challenges shape the emergence of social economy initiatives in Northwestern Ontario, where there must be adaptation to policy frameworks that are geared to the interests of more populated areas in the province.

\section{Relationship with the Land of Northwestern Ontario}

As people pursue livelihood in adaptation to their total environment, forming a blended economy inclusive of the land, it is evident that the biophysical environment is central to how social economies in Northwestern Ontario form. Identification with land is considered central to Indigenous cultures (Kuokkanen, 2011; Natcher, 2009; Royal Commission on Aboriginal Peoples, 1996) and was evident as a key organizing principle in our Bearskin Lake First Nation and Aroland 
Blueberry Foraging case studies (Table 1). The importance of the land was also evident in how the Blueberry Blast was envisioned from its inception and in how the founders of Willow Springs connect horticultural therapy to their boreal forest environment. The unique relationship with the land evident in our case studies underscores the importance of context and place in understanding social economies (Amin, Cameron, \& Hudson, 2002).

Through these case studies we have discussed ways in which the social economy appears to operate uniquely in Northwestern Ontario. Further analysis and review of the literature suggests that the roots of these unique processes may lie in the historical layers of human interaction with this particular landscape. Northwestern Ontario has been home to Indigenous people since the post-glacial era beginning 10,000 years ago. The Anishinaabe (Ojibway language) people of the area developed ways to survive the rigours of a northern climate that profoundly connected land, language, and culture, and involved extensive trade networks with other Indigenous communities northward to Hudson Bay, and southward to communities along the Great Lakes and down the Mississippi River (Wright \& Carlson, 1987). This trade included agriculturally-grown food, such as corn from more southerly climates (Belshaw, 2012; Waisberg \& Holzkamm, 1993). Thus, survival in place and the transmission of the values of sharing and interdependency were well established in the area before Europeans arrived. Indeed, Wuttunee (2009) suggests that Indigenous modes of economic and social organization are akin to concepts of social economy and predate current articulation of the social economy. Further strengthening this position, Fontan and Shragge (2000) argue that the social economy has been with us as long as survival behaviours have been communal and that all share in the results of these activities. Natcher (2009) proposes that subsistence economies demonstrate considerable resilience and these subsistence activities are fundamental in maintaining the health and well-being of northern communities.

These Indigenous modes of economic and social organization were predominant when the Europeans arrived and we argue that it continues to influence people's interactions with each other, with the land, and with the capitalist economy (Southcott, 2009). The first European people to interact extensively with the Indigenous people of the area were the French fur traders (Day, 2000; Bishop, 1970; Dunning, 1959). This relationship was reciprocal, rooted in trade, and extended into the social and cultural aspects 
of both communities. Intermarriage, for example, was common and often supported trade relationships and alliances. The fur trade was the most pervasive influence on economic and political development in Western Canada (including Northwestern Ontario) between 1660 and 1870, and acted as an integrative force between the Indigenous and French. A successful fur trade rooted in the northern climate required co-operation. With France ceding Canada to Britain in 1763, the relationship between European traders and Indigenous people changed. Over time, the British and then Canadian governments pushed to formalize the relationship particularly around access to land and resources through treaties, and to assimilate Indigenous people and cultures into the dominant society (Morrison, 2003; Lytwyn, 1995). However, as we discovered in our case studies, the Indigenous communities pervasive throughout Northwestern Ontario held strong to transmitting values of sharing and interdependency as the core Indigenous modes of economic and social organization.

The geography and climate in which these four case study initiatives have emerged requires that people interact with the land, with each other, and with wider trade and economic systems in diverse ways, and this has been the case for as long as Indigenous people have been in the area. With the arrival of the British in particular, and with the gradual ascendance of the capitalist economy in the area, the ecosystem of trade and economics has come to play a greater role in the human pursuit of livelihood. However, as noted in the Bearskin Lake case study, this is understood to be a temporary phase, with the land and people's connection to it being more stable and important. In all of the case studies we see awareness that there needs to be the capacity and infrastructure to facilitate uniquely northern land-based food acquisition and regional trade, and that these play a central role in driving our northern social economy initiatives.

Social economies emerge as they do as a result of their embeddedness in a particular context, shaped by the people, the cultures, and landscape of place (Tremblay, 2012; Jan, 2009; Amin et al., 2002). This contention that social economies are profoundly place-based has been supported by the findings of our four case studies from Northwestern Ontario. These social economy initiatives leverage unique aspects of the landscape such as blueberry foraging and horticultural therapy in the boreal forest. They respond to limitations of the capitalist economy unique to northern and remote communities, such as transportation and communication 
challenges. They also incorporate elements of a felt connection to the land and the values of interdependency that may be rooted in the Indigenous history of this part of Canada. This interdependency within diverse ecosystems further results in the blended form of social economy we saw in our case studies.

The complexity science lens provides perspective on the role of place in these social economy initiatives. The interactions of people with each other and their biophysical, social, and economic environments results in adaptations uniquely grounded in the total human ecosystem. These varied adaptations reflect and enhance the resilience of these northern communities, for whom the dominant economy cannot always be assumed to be the only ecosystem supporting survival. Further research on the concept of eco-diversity (Nyssens \& Petrella, 2010) and its role in northern communities is warranted. In this article, we presented the case that the social economy must be understood in the context of place. In the four initiatives studied in Northwestern Ontario, the historical, geographical, and social context has shaped uniquely adaptive and blended economies driven by the aim of living life well.

\section{References}

Amin, A. (2009). Locating the social economy. In A. Amin (Ed.), The social economy: International perspectives on economic solidarity (pp. 3-21). London, UK: Zed Books.

Amin, A., Cameron, A., \& Hudson, R. (2002). Placing the social economy. London: Routledge.

Amyot, S., Downing, R., \& Tremblay, C.2010. Public policy for the social economy: Building a people-centred economy in Canada. Public Policy Paper Series Number 03 - June 2010. Canadian Social Economy Research Partnerships. University of Victoria: Canadian Social Economy Hub.

Ashby, W.R. (1962). Principles of the self-organizing system. In H. Von Foerster and G.W. Zopf, Jr. (Eds.), Principles of self-organization: Transactions of the University of Illinois Symposium (pp. 255-278). London, UK: Pergamon Press.

Batty, E.\& Cole,I. (2010). Resilience and the recession in six deprived communities: Preparing for worse to come? York, UK: Joseph Rountree Foundation Paper.

Berinyuy, C.M., et al. (2014). The adaptive cycle as a lens for service-learning: Community engagement partnerships. Partnerships: A Journal of ServiceLearning \& Civic Engagement, 5(2), 153-177. 
Bishop, C.A. (1970). The Northern Ojibwa and the fur trade: An historical and ecological study. Toronto: Holt, Rinehart and Winston.

Bristow, G. (2010). Resilient regions: Re-'place'ing regional competitiveness. Cambridge Journal of Regions, Economy and Society, 3(1), 153-167.

Buttel, F.H., Larson, O. F., \& Gillespie Jr., G. N. (1990). The sociology of agriculture. New York, NY: Greenwood Press.

Canadian Social Economy Research Partnerships. N.D. 2005.Building and strengthening communities through the social economy. Retrieved from http://socialeconomyhub.ca/sites/socialeconomyhub.ca/files/ socialeconomybookletenfinal.pdf

Chantier de l'economie sociale. 2013. Social economy reference guide. Retrieved from http://chantier.qc.ca/wp-content/uploads/2017/08/guide-dereference-sur-1-economie-sociale-anglais.pdf

Charron, A. (2012). The growth of the social economy in Quebec through the unification of the movement since 1996. The Canadian CED Network. Retrieved from https://ccednet-rcdec.ca/sites/ccednet-rcdec.ca/files/ccednet/ Alex Quebec paper.pdf

Day, R.J.F. (2000). Multiculturalism and the history of Canadian diversity. Toronto: University of Toronto Press.

Defourny, J., \& Develtere, P. (1999). The social economy: The worldwide making of a third sector. University of Liège: Léconomie sociale au Nord et au Sud.

Downing, R., McElroy, R., Tremblay, C., \& Amyot, S. (2012). Converging agendas for the social economy and sustainable development. In Rupert Downing (Ed), Canadian public policy and the social economy (pp. 329-374). Victoria, BC: University of Victoria. Retrieved from https://dspace.library.uvic.cal bitstream/handle/1828/3863/canadianpublicpolicy ebook April122012. pdf?sequence $=11$ \&isAllowed $=y$

Driben, P. (1986). Aroland is our home: An incomplete victory in applied anthropology. New York: AMS Press.

Dunning, R.W. (1959). Social and economic change among the Northern Ojibwa. Toronto: University of Toronto Press.

Fath, B.D., Dean, C.A., \& Katzmair, H. (2015). Navigating the adaptive cycle: An approach to managing the resilience of social systems. Ecology and Society, 20(2), 24. Retrieved from http://dx.doi.org/10.5751/ES-07467-200224

Folke, C., Carpenter, S.R., Walker, B., Scheffer, M., Chapin, T., \& Rockström, J. (2010). Resilience thinking: Integrating resilience, adaptability and transformability. Ecology and Society, 15(4), 20. Retrieved from https://www. ecologyandsociety.org/vol15/iss4/art20/ 
Food Secure Canada. (2017). Building a healthy, just and sustainable food system: Food Secure Canada's recommendations for A Food Policy for Canada. Retrieved from https://foodsecurecanada.org/sites/foodsecurecanada.org/ files/attached files/policy brief a food policy for canada sept 28 by fsc. pdf

Fontan, J., \& Shragge, E. (2000). Social economy: International debates and perspectives. Montreal: Black Rose Books.

Golden-Biddle, K., \& Locke, K. (1993). Appealing work: An investigation of how ethnographic texts convince. Organization Science, 4(4), 595-616.

Gunderson, L.H., \& Holling, C.S. (2002). Resilience and adaptive cycles. In L.H. Gunderson \& C.S. Holling (Eds.), Panarchy: Understanding transformations in buman and natural systems (pp 25-62). Washington, DC: Island Press.

Hawkins, S. (2014, 19 March). Local food profile: Arthur Shupe - bringing the wild home. Dryden: Dryden Observer.

Holland, J.H. (2006). Studying complex adaptive systems. Journal of Systems Science and Complexity, 19, 1-8. https://doi.org/10.1007/s11424-006-0001-z

Holling, C.S. (2001). Understanding the complexity of economic, ecological, and social systems. Ecosystems 4(5), 390-405. https://doi.org/10.1007/ s10021-001-0101-5

Holling, C.S. (1973). Resilience and stability of ecological systems. Annual Review of Ecology and Systematic, 4, 1-23. https://doi.org/10.1146/annurev. es.04.110173.000245

Indigenous and Northern Affairs Canada. Treaty 3 between her Majesty the Queen and the Saulteaux tribe of the Ojibbeway Indians at the Northwest Angle on the Lake of the Woods with Adhesions. Retrieved from https:// www.aadnc-aandc.gc.ca/eng/1100100028675/1100100028679

Indigenous and Northern Affairs Canada. Treaty 5 between her Majesty the Queen and the Saulteaux and Swampy Cree Tribes of Indians at Beren's River and Norway House with Adhesions. Retrieved from https://www. aadnc-aandc.gc.ca/eng/1100100028699/1100100028700

Indigenous and Northern Affairs Canada. The James Bay Treaty-Treaty No. 9 (Made in 1905 and 1906) and Adhesions Made in 1929 and 1930. Retrieved from https://www.aadnc-aandc.gc.ca/eng/1100100028863/1100100028864

Indigenous and Northern Affairs Canada. Treaty Texts - Ojibewa Indians of Lake Superior. Retrieved from https://www.aadnc-aandc.gc.ca/ eng/1100100028978/1100100028982 
Jan, M. (2009). In search of ... exploration of the boundaries, scope and definitions of the social economy: A discussion paper. Social Economy and Sustainability Research Network. Halifax: Mount St. Vincent University.

Jennings, D. (2012). Summary report and literature review. New Zealand Community Economic Development Trust.

Kauffman, S.A. (1993). The origins of order: Self-organization and selection in evolution. New York, NY: Oxford University Press.

Kuokkanen, R. (2011). Indigenous economies, theories of subsistence, and women. American Indian Quarterly. University of Nebraska Press, 35(2), 215-240.

Lytwyn, V. P. (1995). The Anishinabeg and the fur trade. In T.J. Trnrud \& A.E. Epp (Eds.), Thunder Bay: From rivalry to unity (pp. 16-36). Thunder Bay, ON: Thunder Bay Historical Museum Society, Revised October 2002.

Levesque, B. \& Mendell, M. (2005). The social economy: Approaches, practices and a proposal for a new community-university alliance (CURA). Journal of Rural Cooperation, 33(1), 21-45.

Liu, J., et al. (2007). Complexity of coupled human and natural systems. Science, 317, 1513-1516. https://doi.org/10.1126/science.1144004

Malloy, A., McFeely, C., \& Connelly, E. (1999). Building a social economy for the new millennium. Derry: Guildhall Press/NICDA.

Mitchell,M.(2009). Complexity a guided tour. Toronto: Oxford University Press.

Moore, M.L. \& Westley, F. (2011). Surmountable chasms: Networks and social innovation for resilient systems. Ecology and Society, 16(1). [on-line] http://www. ecologyandsociety.org/vol16iss1/art5/

Morrison, J. (Ed). (2003) Lake Superior to Rainy Lake: Three centuries of fur trade history. Thunder Bay: Thunder Bay Historical Museum Society.

Moulaert, F., \& Ailenei, O. (2005). Social economy, third sector and solidarity relations: A conceptual synthesis from history to present. Urban Studies 42(11), 2037-2053.

Nyssens, M. \& Petrella, F. (2010). The social and solidarity economy and Ostrom's approach to common pool resources: Towards a better understanding of institutional diversity. In J.-L. Laville, D.R. Young, \& P. Eynaud (Eds.), Civil society, the third sector and social enterprise: Governance and democracy (pp. 178-190). New York: Routledge.

Natcher, D.C. (2009). Subsistence and the social economy of Canada's Aboriginal north. The Northern Review, 30, 83-98. https://thenorthernreview.ca/index. $\mathrm{php} / \mathrm{nr} / \mathrm{article} / \mathrm{view} / 6$ 
Nelson, C.H. et al. (in press). Understanding social economy through a complexity lens in Northwestern Ontario: Four Case Studies. Canadian Food Studies.

Nelson, C.H., \& Stroink, M.L. (2014). Accessibility and viability: A complex adaptive systems theory approach to a wicked problem for the local food movement. Journal of Agriculture, Food Systems and Community Development. https://doi.org/10.5304/jafscd.2014.044.016

Ninacs, W. (2002). A review of the theory and practice of social economy/ Économie sociale in Canada. Ottawa: Social Research and Demonstration Corporation.

Ott, A. (1851) Traite d'e'conomie sociale. Paris: Renou-éditeur.

Ostrom, E. (2009). A general framework for analyzing sustainability of social-ecological systems. Science, 325, 419-422. https://doi.org/10.1126/ science. 1172133

Ostrom, E. (2010). Beyond markets and states: Polycentric governance of complex economic systems. American Economic Review, 100-133.

Ostrom, E. (1990). Governing the commons: The evolution of institutions for collective action. Cambridge: Cambridge University Press.

Restakis, J. (2006). Defining the social economy: The BC context Prepared for the BC Social Economy Roundtable. Retrieved from http://www.msvu.ca/ socialeconomyatlantic/pdfs/DefiningSocialEconomy FnlJan1906.pdf

Royal Commission on Aboriginal Peoples, (1996). Restructuring the relationship $\left(2^{\text {nd }} \mathrm{vol}\right)$. Ottawa: Canada Communication Group.

Simmie, J., \& Martin, R. (2010). The economic resilience of regions: Towards an evolutionary approach. Cambridge Journal of Regions, Economy and Society, 3, 27-43. https://doi.org/10.1093/cjres/rsp029

Sonnino, R., \& Griggs-Trevarthen, C. (2013). A resilient social economy? Insights from the community food sector in the UK. Entrepreneurship and Regional Development, 25(304), 272-292. https://doi.org/10.1080/08985626.2012.71 $\underline{0268}$

Southcott, C., \& Walker, V. (2009). A portrait of the social economy in Northern Canada. The Northern Review, 30,13-36. https://thenorthernreview.ca/index. $\mathrm{php} / \mathrm{nr} / \mathrm{article} / \mathrm{view} / 3$

Southcott, C. (2009). Introduction: The social economy and economic development in northern Canada. The Northern Review, 30, 3-11. https:// thenorthernreview.ca/index.php/nr/article/view/2

Stacey, R.D. (1996). Complexity and creativity in organizations. San Francisco: Berrett-Koehler Publishers. 
Stroink,M.L., \& Nelson, C.H.(2009). Aboriginal health learning in the forest and cultivated gardens: Building a nutritious and sustainable food system. Journal of Agromedicine, 14, 263-269. https://doi.org/10.1080/10599240902739737

Stroink, M.L., \& Nelson, C.H. (2012). Understanding local food behaviour and food security in rural First Nation communities: Implications for food policy. The Journal of Rural and Community Development, 7(3), 65-82. Retrieved from http://www.jrcd.ca/viewarticle.php?id=670\&layout=abstract

Stroink, M.L., \& Nelson, C.H. (2013). Complexity and food hubs: Five case studies from Northern Ontario. Local Environment, 18(5), 620-635. https:// doi.org/10.1080/13549839.2013.798635

Tremblay, C. (2012). Advancing the social economy for socio-economic development: An international perspective. In Rupert Downing (Ed)., Canadian Public Policy and the Social Economy (pp. 13-60.). Victoria, BC: University of Victoria.

Waisberg, L.G., \& Holzkamm, T.E. (1993). A tendency to discourage them from cultivating: Ojibwa agriculture and Indian Affairs Administration in Northwestern Ontario. Ethnohistory, 4O(2), 175-211. http://links.jstor.org/ sici?sici $=0014-1801 \% 28199321 \% 2940 \% 3$ A2\%3C175\%3A\%22TTDTF\%3 E2.0.CO\%3B2-H

Walker, B. \& Salt, D. (2006). Resilience thinking: Sustaining ecosystems and people in a changing world. Washington: Island Press.

Walras, L. (1896) Etudes d'économie sociale (Théorie de la répartition de la richesse sociale). Lausanne: F. Rouge.

Weaver, W. (1948). Science and complexity. American Scientist, 36, 536.

Westley, F. R., Tjornbo, O., Schultz, L., Olsson, P., Folke, C., Crona, B., \& Bodin, Ö. (2013). A theory of transformative agency in linked social-ecological systems. Ecology and Society, 18(3), 27. https://doi. org/10.5751/ES-05072-180327

Westley, F., \& Antadze, N. (2010). Making a difference: Strategies for scaling social innovation for greater impact. The Innovation Journal: The Public Sector Innovation Journal, 15(2).

Wiese, S.L., Vallacher, R.R., \& Strawinska, U. (2010). Dynamical social psychology: Complexity and coherence in human experience. Social and Personality Psychology Compass, 4(11), 1018-1030. https://doi.org/10.1111 j.1751.9004.2010.00319

Wilkinson, K.P. (1991). The community in rural America. Westport, CT. Greenwood Press. 
Wright, J.V., \& Carlson, R.L., (1987). Prehistoric trade. In R.C. Harris (Ed.), Historical atlas of Canada, Vol. 1: From the beginning to 1800 (p. 14). Toronto: University of Toronto Press.

Wuttunee, W. (2009). Aboriginal perspectives on the social economy. Living economics: Canadian perspectives on the social economy, co-operatives, and community economic development. Toronto, ON: Emond Montgomery Publications.

\section{Acknowledgements}

Thank you for the support through the Northern Node of the Nourishing Communities Initiative funded by SSHRC Insight Grant Social Economy of Food: Informal, Under-recognized Contributions to Community Prosperity and Resilience Project. Thank you to the Organizing Committee: Drs. Lindsay Galway, Charles Levkoe, and Rebecca Schiff who encouraged our participation in the Workshop on Regional Centres and the Sustainability of Canada's Rural and Northern Landscapes. This specific article is the result of our presentation and group discussions from this workshop held May 10-11, 2018, at Lakehead University in Thunder Bay, Ontario. Thank you to the research assistants for their enthusiasm in learning about northern social economies: Rachel Kakegamic, Esther McKay, William Stolz, and Allison Streutker.

\section{Authors}

Connie Nelson is professor emeritus in the School of Social Work at Lakehead University in Thunder Bay, Ontario.

Mirella Stroink is associate professor and chair of the Department of Psychology at Lakehead University in Thunder Bay, Ontario. 